\title{
President-Elect's Message: Internationalization of the International Association for Dental Research
}

\author{
JAMES K. AVERY
}

School of Dentistry, University of Michigan, Ann Arbor, Michigan

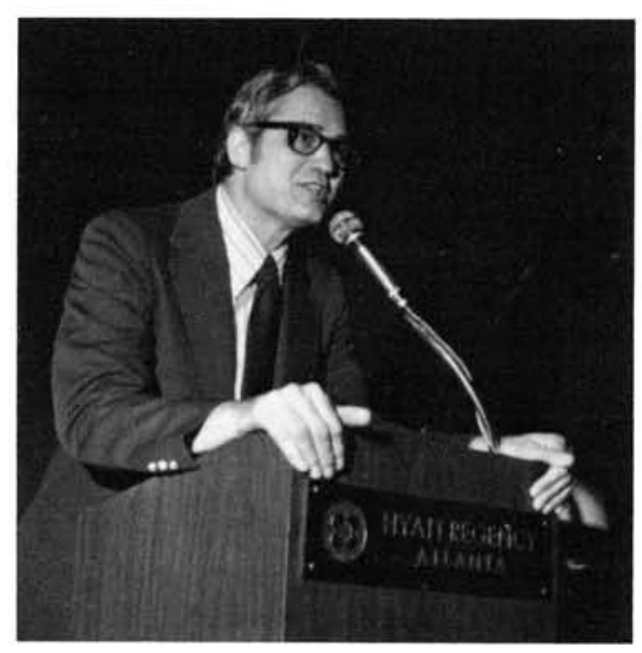

When the month of March arrives usually two things happen to me. I go to the IADR meetings and I come down with the flu the week before. It's happened a dozen times in the past and this year was no exception. I think of it as my welcome to the spring. Some years ago at Rochester, New York, I used to blame my March malady on the Eastman Dispensary Bus, better known by us as "the hearse." Dr. Bibby kindly loaned this conveyance to us for transportation to the annual IADR meetings. It was old and drafty but we appreciated having the use of it. Anyway, I owe a very large debt of gratitude to such great friends as Jack Hein, Wah Leung, Emmett Costich, and Dave Mitchell who kept me alive through those early meetings and also supplied me with the scholarly stimulus so typical to the Rochester group. I still remember the time Dave Mitchell handed me a glass of Pluto Water at the IADR meeting at French Lick Springs, which proved to be a new cure for the flu and a lot of other things.

Presented at the opening meeting of the 52nd general session of the IADR on March 21, 1974 at the Hyatt Regency Hotel, Atlanta, Georgia.
In March 1972 at our annual meeting in Las Vegas, officers for the North American Division were elected, a constitution was ratified, and 37 section councilors became the representative body of the North American Division. The International Association for Dental Research developed its own council of 19 , consisting of 13 representatives from seven divisions and six officers (Chart). The formation of the North American Division had been made official earlier, on March 23, 1952 , at the annual meeting in Colorado Springs. But for the following 20 years, the presidents of the IADR served as North American Division presidents as well. Short business meetings of the North American Division were held at each meeting. Some of the historical events in the development of each division are interesting and lead us to a better understanding of the importance of the developments of these past several years. I am indebted to our historian, Dr. Orland, who allowed me to peruse the page proofs of The First Fifty-Year History of the International Association for Dental Research. This best seller will go on sale at this meeting.

The IADR is 54 years old, dating back to 1920. William Gies, our founder, watched the growth of sections, which was the early characteristic of IADR. By 1936 he reported 26 sections in eight nations. There was a gradual transition from growth of sections to a more recent growth of divisions. As we think internationally it is important to know historically how each of the other divisions developed.

The Scandinavian Division was unanimously approved by the IADR Council in 1969. The history of this division extends back to 1917 when the NOF, Nordic Odontological Society, was founded in Gothenburg, Sweden. The objective of the NOF was to promote dental science and teaching. It took over the journal, Odontologisk Tid- 


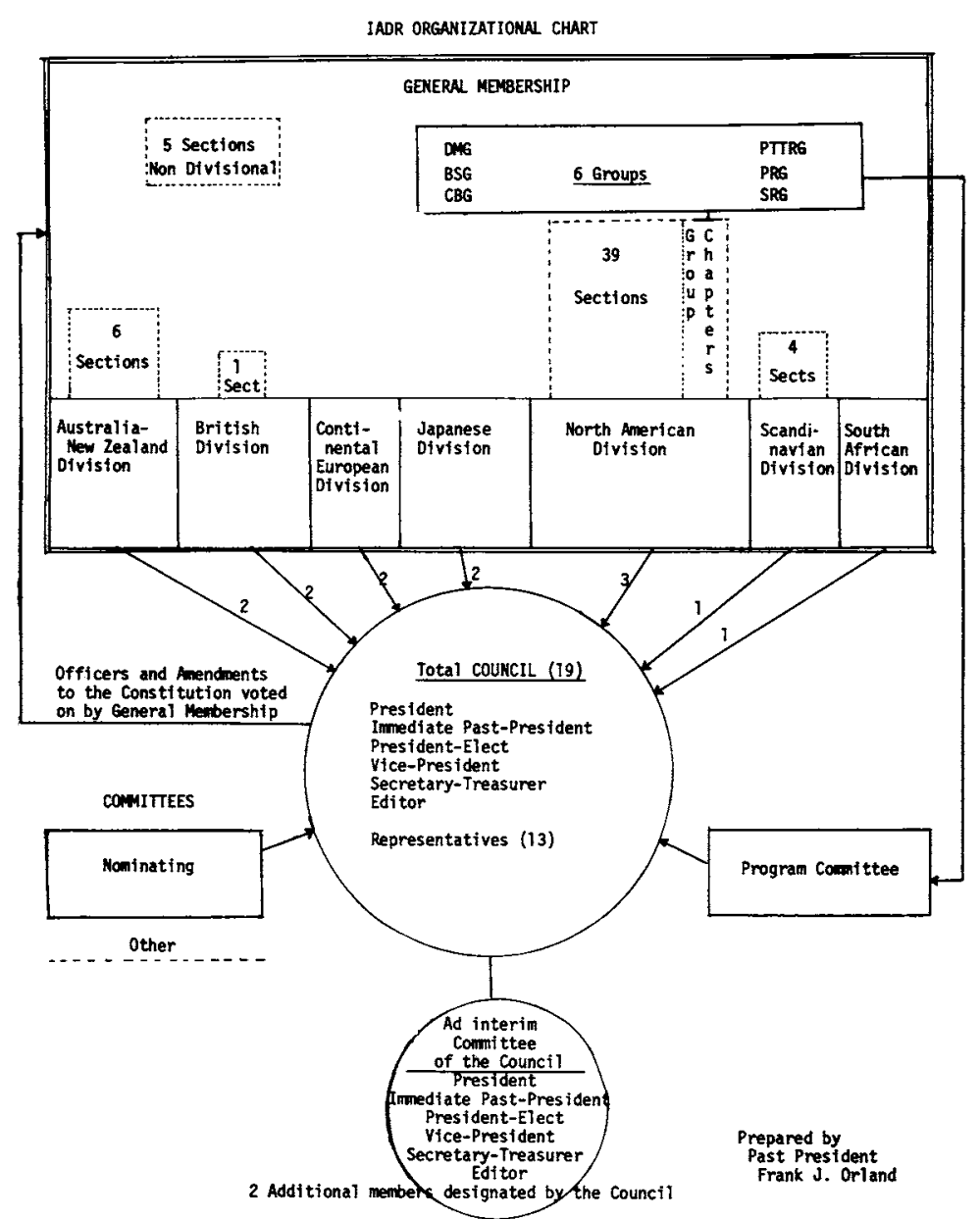

skrift. Since 1917, 34 annual meetings have been held, except during the war years. An IADR section was founded in Denmark in 1950, in Finland and Norway in 1958, and in Sweden in 1969. All merged in 1969 to form the NOF Scandinavian Division of the IADR, and the NOF journal became the Scandinavian Journal of Dental Research with all papers published in English. This year there are 104 IADR members in Scandinavia.

Another division with a long history is the British Division. Its history as part of the IADR dates back to the formation of a London Section in 1931 with such famous names among its founding members as Sir Wilfred Fish, F. N. Doubleday, and F. Colyer. Inspiration for this move had been gained from attending the eighth annual meeting of the IADR in Toronto in 1930.
During the war the London section was forced to postpone its activities, but in 1953 the British Division was formed. Members of this division represent England, Scotland, Wales, Northern Ireland, and the Republic of Ireland. This division has had independent officers and meetings since 1953. They have had 18 regular meetings since that time. One hundred thirty-nine papers were read at the annual meeting in Birmingham, England in 1970. Membership presently is 331 .

Australia got its start with the organization of the Victorian Section of the Dental Materials Group in 1951, which grew to 51 members by 1969. This was followed by formation of the Australian Section in 1961 which grew in size until divisional status was desired and approved by the Council in 1968. At the annual meeting that year, New Zealand requested to become a part of this 
division and thus, the Australian-New Zealand Division came into being in 1969. By 1970 there were 130 full members and 30 associate members of this division. This division now consists of sections in Brisbane, Sydney, Melbourne, Adelaide, and Perth as well as New Zealand. Today with a total of 181 members, each section has its own president or chairman and divisional councilor.

The Japanese Division was founded in 1954 at the 32nd annual meeting of the IADR. Previous to this, a Japanese section had been founded in 1950 when Dr. George Paffenbarger vistted the country as part of a dental mission. It seemed fitting that when Dr. Paffenbarger became president of the IADR he introduced their proposal to the Council for approval. Eighteen divisional meetings have been held since 1954 and membership has grown to the present 193 . All abstracts of papers presented have been published in the Journal of Dental Research. Because the IADR meetings have been so far away, this division sought a way for improved communication. They formed $\mathbf{a} \mathrm{Pa}$ cific Congress of Dental Research to encourage idea exchange in that area of the world. This has been our fastest growing division in the past year.

The Continental European Division was approved by the Council of the IADR at the 42nd general meeting in 1964. The following countries are represented in this confederation: West Germany, Switzerland, France, Italy, Belgium, Netherlands, Luxemburg, Liechtenstein, Malta, Czechoslovakia, Greece, and Hungary. There are no sections in this division, but there is a unifying resolve to bring dental research workers of these countries together yearly. The first and tenth meetings were held in Strasbourg, France. Other meetings have been held in Zurich and Geneva, Switzerland; Werzburg and Erlangen, Germany; Paris, France; Groningen and Nijmegen, the Netherlands; and Rome, Italy. To be a member of this division requires several published papers in dental research. Membership has doubled in this division since 1964 to 123 members.

The South African activity in the IADR dates back to 1934 when a section was formed in Johannesburg. Later, this section became inactive until Dr. Melvyn Shear stirred up interest and initiated a meeting for divisional status in 1966. Ample interest was created and, thus, this division came into being in 1966. Annual meetings have been held each year at locations such as Johannesburg, Pretoria, University of Witwatersrand, and Cape Town. This year there are 107 regular members and 50 associates.

Perhaps the fact the North American Division was the last of the seven divisions to fully develop by electing its own officers and developing its own constitution has prevented us from appreciating the full range of our international contributions to the IADR. This year our organization is 54 years old. In 54 years the IADR meeting has not left the North American continent. You are now looking forward to your first North American Division Scientific Program next April in New York completely independent of the IADR meeting in London. It remains to be seen how this plan of rotation will work out.

Only last year, President Skougaard proposed the IADR meet outside North America more often than every five years. At that rate, if our current lifespan is 60 to 65 years and considering there are seven divisions, the IADR would assemble in each division twice in our lifetime. On Tuesday of this week, the Council, acting on existing bylaws, stated that the place and time of each annual IADR meeting will be determined by the Council. Dr. Sreebny, chairman of the foreign relations committee, announced that like the British, the Japanese, Scandinavian, and South African Divisions have offered invitations to host the annual meetings. Further invitations from the Continental European and Australian-New Zealand Divisions were enthusiastically presented at that meeting. Thus, in the next few years, IADR meetings could be located in London (1975), American Division (1976), Scandinavia (1977), and Japan (1978). Continental European, Australian-New Zealand, and South African Divisions would follow. An increase in the number of divisions is another big factor concerning future meeting locations. I hasten to suggest now that our internationalization seems complete and that the Council will provide a sensible balance of meetings on this continent and the others. Measurable strengths well be maintained by periodic meetings with the American Division.

Meanwhile, plans are advancing for the 53rd annual meeting in London in April of 1975. Already the organizing and program committees have started planning for an out- 
standing meeting. With the lack of knowledge of attendance expected, each member was sent a questionnaire asking whether or not he planned to attend and if he planned to present a paper. Response to the questionnaires indicates that participation will be large and truly international. The meetings are scheduled for the Imperial College, London. Adequate meeting rooms, reception and registration facilities, and committee rooms are available at the Imperial College. Is is an impressive institution and we will enjoy attending the meetings there.

There are other ways that we can and should strengthen our international bonds. We should press to clarify the roll that we play with the Federation Dentaire Internationale. Our interest lies most closely in the commission on dental research within this organization. Dr. Sreebny and his International Relations Committee reported at the Council meeting that the IADR has received an official invitation from the Scientific Assembly Committee of the Federation
Dentaire Internationale to sponsor a scientific program at the 1975 Congress in Chicago. The IADR is an affiliate member organization of the Federation Dentaire Internationale and the full meaning of this affiliation must be clarified. The IADR should be the research science arm of the Federation Dentaire Internationale.

Again, on the international scene, we are all aware of the Sixth International Conference of Oral Biology June 3-5, 1974 in Toronto organized by Dr. Norton Ross and his committee. These truly international meetings have given great professional satisfaction to the leading scientists presenting data on the subject of the conference and provided inspiration to the dental researchers of the host country.

Finally, with reactivation of our Senior Foreign Dental Scientist Fellowship Program we can conclude this has been a good year for the international aspects of the IADR. Let us now look forward to a great next year, and many more to come. 


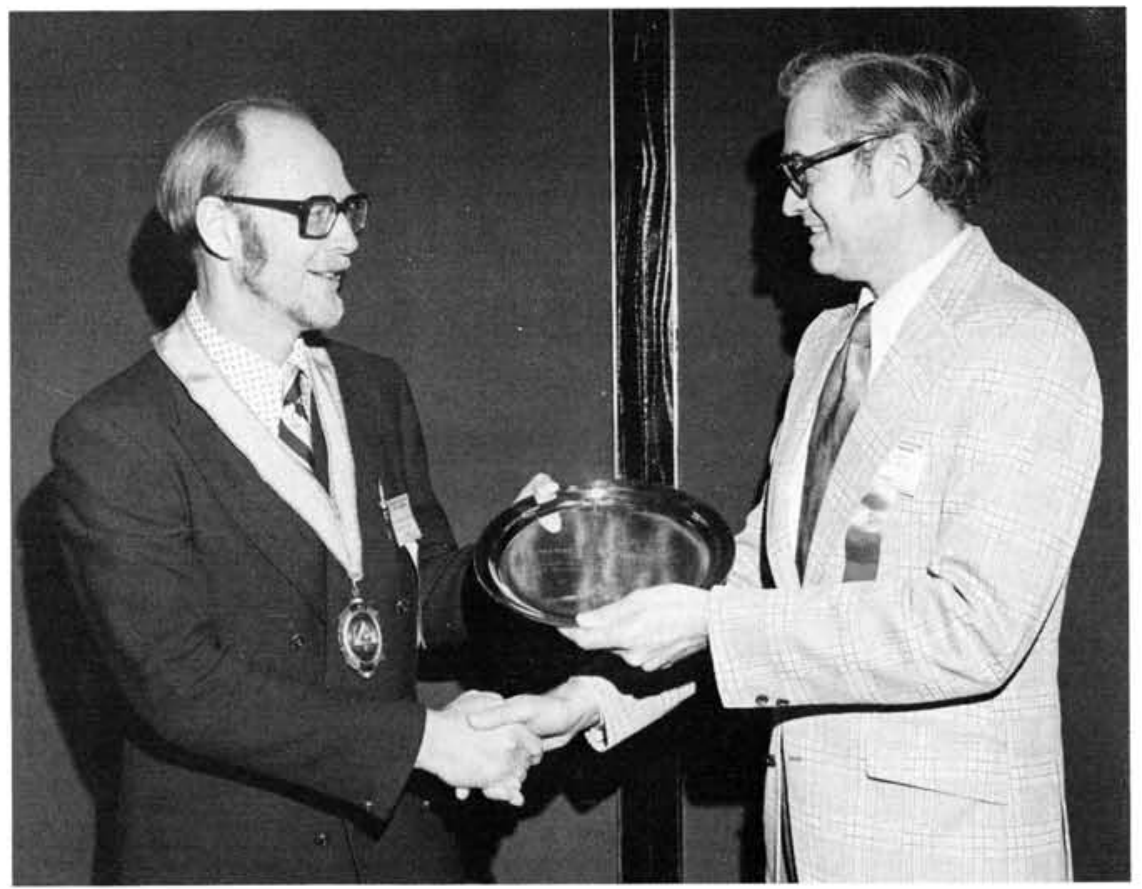

President Mogens R. Skougaard (left) receives sterling silver tray from President-Elect James $\mathrm{K}$. Avery in appreciation for his dynamic leadership of the Association during the past year. 